\title{
Role of NO/cGMP Signaling Pathway in Cardiac Ischemic Tolerance of Chronically Hypoxic Rats
}

\author{
P. ALÁNOVÁ ${ }^{1,2}$, F. KOLÁŘ $\check{R}^{1}$, B. OŠŤÁDAL ${ }^{1}, J$. NECKÁ ${ }^{1}$ \\ ${ }^{1}$ Institute of Physiology, Czech Academy of Sciences, Prague, Czech Republic, ${ }^{2}$ Department \\ of Physiology, Faculty of Science, Charles University in Prague, Prague, Czech Republic
}

Received October 2, 2014

Accepted December 5, 2014

On-line March 24, 2015

\begin{abstract}
Summary
It has been suggested that increase in acute nitric oxide (NO) or cyclic guanosine monophosphate production may be involved in cardioprotection induced by chronic hypoxia $(\mathrm{CH})$. We studied the effect of NO donor molsidomine and phosphodiesterase type 5 inhibitor sildenafil on myocardial ischemia/reperfusion (I/R) injury in rats adapted to $\mathrm{CH}$. Male Wistar rats were exposed to continuous hypoxia in a normobaric chamber $\left(10 \% \mathrm{O}_{2}\right.$, 4 weeks). Rats received either saline, molsidomine $(10 \mathrm{mg} / \mathrm{kg}$ body weight, i.v.) or sildenafil $(0.7 \mathrm{mg} / \mathrm{kg}$ body weight, i.v.) $30 \mathrm{~min}$ before ischemia. Control rats were kept under normoxia and treated in a corresponding manner. Adaptation to $\mathrm{CH}$ increased the myocardial ischemic tolerance. Acute treatment with either molsidomine or sildenafil significantly reduced infarct size in normoxic rats and further enhanced cardioprotection induced by $\mathrm{CH}$. However, the cardioprotective effect of $\mathrm{CH}$ on $\mathrm{I} / \mathrm{R}$ injury was not additive to the cardioprotection provided by the drugs.
\end{abstract}

\section{Key words \\ Hypoxia - Cardioprotection - Nitric oxide - Molsidomine • Sildenafil}

\section{Corresponding author}

P. Alánová, Department of Developmental Cardiology, Institute of Physiology CAS, Vídeňská 1083, 14220 Prague 4, Czech Republic. E-mail: petra.alanova@biomed.cas.cz

Ischemic heart disease belongs to the leading cause of mortality worldwide. Therefore, therapeutic strategies trying to protect the myocardium against ischemia/reperfusion (I/R) injury have been widely studied. Many experimental studies have repeatedly confirmed that heart can be protected from I/R injury by cardioprotective phenomena such as adaptation to chronic hypoxia $(\mathrm{CH})$ or different types of conditioning (Peart and Headrick 2009). It was demonstrated repeatedly that adaptation to $\mathrm{CH}$ can reduce infarct size, number of ischemic arrhythmias and postischemic contractile dysfunction (reviewed by Oštádal and Koláŕ 2007). However, compared to the temporary character of conditioning, these cardioprotective effects may persist for weeks or even months after the cessation of hypoxic exposure (Neckář et al. 2004). Although the beneficial effect of $\mathrm{CH}$ on various manifestations of $\mathrm{I} / \mathrm{R}$ injury has been known for many years, the molecular mechanism remains far from being understood. $\mathrm{CH}$, besides the other changes, increases the production of nitric oxide (NO) in the myocardium (Ding et al. 2005, Fitzpatrick et al. 2005) suggesting that enhanced NO generation plays a role in its protective mechanism. Many beneficial signals of NO are mediated by cyclic guanosine monophosphate (cGMP), produced by soluble guanylate cyclase after NO activation. In the heart, cGMP is degraded by phosphodiesterase type 5 (PDE5; Giordano et al. 2001). Inhibition of PDE5 activity would be then expected to protect the ischemic heart by reducing the breakdown of cGMP in $\mathrm{CH}$ hearts.

In the present study, we tested a hypothesis that acute administration of NO donor molsidomine or PDE5 inhibitor sildenafil can further reduce myocardial infarct size in $\mathrm{CH}$ rats subjected to I/R injury. Adult male Wistar 
rats (300-350 g) were exposed to $\mathrm{CH}\left(10 \% \mathrm{O}_{2}\right)$ in a normobaric chamber equipped with hypoxic generators for 4 weeks. Control rats were kept for the same period of time at room air. Animals were randomly assigned to six groups; normoxic $(\mathrm{n}=10)$ and $\mathrm{CH}(\mathrm{n}=10)$ rats treated with saline, normoxic $(\mathrm{n}=11)$ and $\mathrm{CH}(\mathrm{n}=11)$ rats treated with molsidomine (Sigma Aldrich, St. Louis, MO, USA; $10 \mathrm{mg} / \mathrm{kg}$ body weight, i.v.), normoxic $(\mathrm{n}=8)$ and $\mathrm{CH}$ $(n=10)$ rats treated with sildenafil (Viagra, Pfizer, Kent, Great Britain; $0.7 \mathrm{mg} / \mathrm{kg}$ body weight, i.v.) $30 \mathrm{~min}$ before coronary artery occlusion. Molsidomine and sildenafil doses were selected according to Chander and Chopra (2005) and Koneru et al. (2008), respectively. All experiments were performed in accordance with the Guide for the Care and Use of laboratory Animals published by the US National Institutes of Health (NIH Publication No. 85-23, revised 1996) and approved by the Ethics Committee of the Institute of Physiology, Czech Academy of Sciences.

Susceptibility to myocardial injury was evaluated in anesthetized (sodium pentobarbital; $60 \mathrm{mg} / \mathrm{kg}$ body weight) open-chest pump-ventilated (6870 strokes/min, tidal volume of $1.2 \mathrm{ml} / 100 \mathrm{~g}$ body weight) rats. Cannulations of jugular vein (drug administration) and carotid artery (mean arterial pressure recording) were accomplished. Left thoracotomy was performed to expose the heart; myocardial ischemia was induced by occlusion of left anterior descending coronary artery for $20 \mathrm{~min}$, followed by 3 -h reperfusion. The area at risk and the infarct size were delineated by staining with potassium permanganate and 2,3,5-triphenyltetrazolium chloride, respectively, and determined by a computerized planimetric method. Detailed description of the experimental procedures is given elsewhere (Neckář et al. 2004). Data are presented as mean values \pm SEM. GraphPad Prism software was used and statistical evaluations were done using one-way analysis of variance with the Newman-Keuls post test. Values exceeding the $95 \%$ probability limits $(\mathrm{P}<0.05)$ were considered statistically significant.

The values of mean arterial pressure (MAP) in selected time intervals of the experimental protocol are shown in Figure 1. Acute molsidomine administration induced a significant decrease in MAP in both normoxic (from $128.3 \pm 4.5$ to $56.6 \pm 4.6 \mathrm{~mm} \mathrm{Hg} ; \mathrm{P}<0.05$ ) and $\mathrm{CH}$ (from $147 \pm 4.3$ to $56.3 \pm 3.4 \mathrm{~mm} \mathrm{Hg} ; \mathrm{P}<0.05$ ) rats; this effect persisted during ischemia. Acute sildenafil administration did not have lasting effect on MAP in normoxic or $\mathrm{CH}$ group. Figure $2 \mathrm{~A}$ shows the myocardial area at risk expressed as the percentage of the left ventricular size. No significant differences occurred among the individual experimental groups; this allowed comparing the average values of infarct size. As shown in Figure 2B, adaptation to $\mathrm{CH}$ induced a significant decrease in infarct size normalized to the area at risk $(40.6 \pm 2.4 \%)$ as compared to the normoxic controls $(56.3 \pm 2.8 \% ; \mathrm{P}<0.05)$. Acute molsidomine or sildenafil administration markedly reduced myocardial infarct size in normoxic rats to $32.3 \pm 6.3 \%$ and $33.7 \pm 8.4 \%$, respectively $(\mathrm{P}<0.05)$ and significantly enhanced protective effect of $\mathrm{CH} \quad(26 \pm 2.5 \%$ and $24.4 \pm 3.5 \%$, respectively; $\mathrm{P}<0.05$ ) in comparison to the saline groups. However, myocardial infarct size in $\mathrm{CH}$ rats treated with molsidomine or sildenafil did not differ from treated normoxic animals.

A

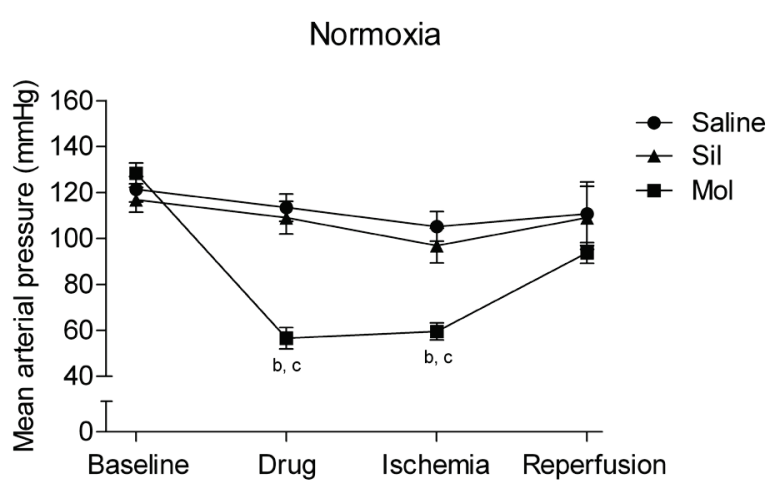

B

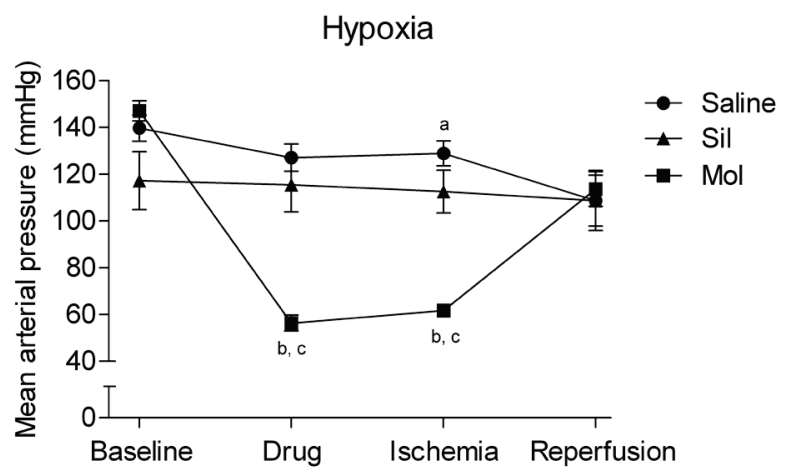

Fig. 1. Mean arterial pressure at baseline, after drug administration, at the end of 20-min coronary artery occlusion and at the end of 3-h reperfusion in normoxic (A) and chronically hypoxic (B) rats treated with saline (Saline), molsidomine (Mol) or sildenafil (Sil). Data are expressed as mean $\pm S E M$; $n=8-11$ per group. ${ }^{a} \mathrm{P}<0.05$ vs. corresponding normoxic group, ${ }^{\mathrm{b}} \mathrm{P}<0.05$ vs. corresponding Saline group, ${ }^{\mathrm{C}} \mathrm{P}<0.05$ vs. Baseline. 
A

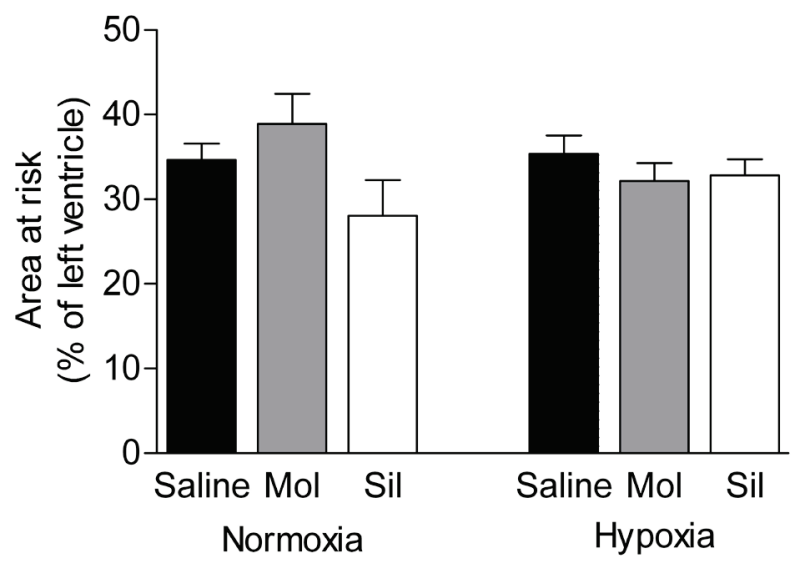

B

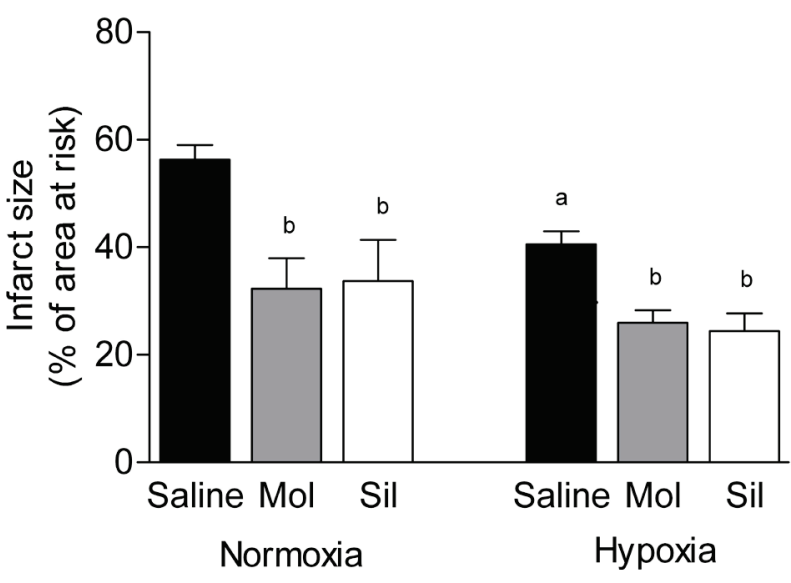

Fig. 2. Area at risk expressed as the percentage of left ventricular size $(\mathbf{A})$ and myocardial infarct size expressed as the percentage of area at risk (B) in normoxic and chronically hypoxic rats treated with saline (Saline), molsidomine (Mol) or sildenafil (Sil). Data are expressed as mean $\pm S E M ; n=8-11$ per group. ${ }^{a} \mathrm{P}<0.05$ vs. corresponding normoxic group, ${ }^{b} \mathrm{P}<0.05$ vs. corresponding Saline group.

It is well known that adaptation to $\mathrm{CH}$ influences myocardial NO production and signaling (Manukhina et al. 2006). As was shown previously, $\mathrm{CH}$ increased concentrations of NO markers like cGMP, nitrites and nitrates in cardiovascular system (Manukhina et al. 1999, Shi et al. 2000, Zhong et al. 2002). Indeed, it appears that adaptation to $\mathrm{CH}$ increases myocardial expression and activity of NO synthases (NOS) though it remains controversial which isoform is responsible for the increased NO production. Ferreiro et al. (2001) showed higher expression of inducible NOS (iNOS) in right atrium samples of children with hypoxemic congenital heart defects. We and others found higher iNOS expression in left ventricle of adult $\mathrm{CH}$ rats (RouetBenzineb et al. 1999, Kolár et al. 2003, Grilli et al.
2003). Moreover, Ding et al. (2005) showed that the acute administration of aminoguanidine, the iNOS inhibitor, abolished cardioprotective effect of $\mathrm{CH}$. On the other hand, in immature rabbit hearts $\mathrm{CH}$ induced the overexpression of endothelial NOS (eNOS) and the molecules regulating eNOS-dependent NO production such as caveolin 3 and heat shock protein 90 (Baker et al. 1999, Shi et al. 2000, 2002). Therefore, species (rat vs. rabbit) and ontogenetic (adult vs. neonatal) differences may account for altered myocardial expression of NOS isoforms in $\mathrm{CH}$ hearts.

Baker's group also analyzed ischemic tolerance in $\mathrm{CH}$ immature rabbit hearts after acute modulation of NO availability. They found that the acute administration of general NOS inhibitor L-NAME before ischemia completely abolished cardioprotective effect of $\mathrm{CH}$ (Baker et al. 1999). Similar findings were also reported for $\mathrm{CH}$ immature rat hearts (Oštádalová et al. 2002). On the other hand, drugs increasing NO/cGMP signaling mimicked cardioprotection in both immature and adult normoxic animals (Nitz and Fiedler 1987, Baker et al. 1999, Ockaili et al. 2002). These results are in line with the present study demonstrating strong infarct size-limiting effect of molsidomine and sildenafil in adult normoxic rat hearts. Although both molsidomine and sildenafil were able to further reduce infarct size in $\mathrm{CH}$ hearts, the combination of both protective measures $(\mathrm{CH}$ and molsidomine or sildenafil) did not provide additive protection to that induced by these drugs in normoxic hearts. Therefore, it seems that the activation of protection by drugs increasing NO/cGMP levels was filled to maximal capacity. Similar results were observed when $\mathrm{CH}$ was combined with classic ischemic preconditioning (Neckář et al. 2002) suggesting that the cardioprotective interventions $(\mathrm{CH}$ and ischemic/ pharmacological preconditioning, respectively) share the same signaling pathways (as was reviewed previously by Oštádal and Kolár 2007).

In conclusion, the present study showed that acute preischemic treatment with NO donor molsidomine or PDE5 inhibitor sildenafil improved cardiac ischemic tolerance not only in normoxic rats but also in animals adapted to $\mathrm{CH}$. However, cardioprotective effect of $\mathrm{CH}$ was not additive to the cardioprotection provided by the drugs. These results suggest the notable role of NO/cGMP signaling pathway in cardioprotection induced by adaptation to $\mathrm{CH}$.

\section{Conflict of Interest}

There is no conflict of interest. 


\section{Acknowledgements}

The study was supported by the Grant Agency of the Charles University in Prague (project GA UK No.
411911 to P.A.) and Czech Science Foundation (grants No. 13-10267 to J.N. and 303/12/1162 to F.K.).

\section{References}

BAKER JE, HOLMAN P, KALYANARAMAN B, GRIFFITH OW, PRITCHARD KA Jr: Adaptation to chronic hypoxia confers tolerance to subsequent myocardial ischemia by increased nitric oxide production. Ann $N Y$ Acad Sci 874: 236-253, 1999.

CHANDER V, CHOPRA K: Renal protective effect of molsidomine and L-arginine in ischemia-reperfusion induced injury in rats. $J$ Surg Res 128: 132-139, 2005.

DING HL, ZHU HF, DONG JW, ZHU WZ, YANG WW, YANG HT, ZHOU ZN: Inducible nitric oxide synthase contributes to intermittent hypoxia against ischemia/reperfusion injury. Acta Pharmacol Sin 26: 315-322, 2005.

FERREIRO CR, CHAGAS ACP, CARVALHO MHC, DANTAS AP, JATENE MB, DE SOUZA LCB, DA LUZ PL: Influence of hypoxia on nitric oxide synthase activity and gene expression in children with congenital heart disease. A novel pathophysiological adaptive mechanism. Circulation 103: 2272-2276, 2001.

FITZPATRICK CM, SHI Y, HUTCHINS WC, SU J, GROSS GJ, OŠŤÁDAL B, TWEDDELL JS, BAKER JE: Cardioprotection in chronically hypoxic rabbits persists on exposure to normoxia: role of NOS and KATP channels. Am J Physiol Heart Circ Physiol 288: H62-H68, 2005.

GIORDANO D, DE STEFANO ME, CITRO G, MODICA A, GIORGI M: Expression of cGMP-binding cGMPspecific phosphodiesterase (PDE5) in mouse tissues and cell lines using an antibody against the enzyme amino-terminal domain. Biochim Biophys Acta 1539: 16-27, 2001.

GRILli A, DE LUTIIS MA, PATRUNO A, SPERANZA L, CATALDI A, CENTURIONE L, TACCARDI AA, DI NAPOLI P, DE CATERINA R, BARBACANE R, CONTI P, FELACO M: Effect of chronic hypoxia on inducible nitric oxide synthase expression in rat myocardial tissue. Exp Biol Med (Maywood) 228: 935-942, 2003.

KOLÁŘ F, SZÁRSZOI O, NECKÁŘ J, PECHÁŇOVÁ O, MIKOVÁ D, HAMPL V, OŠŤÁDAL B: Role of nitric oxide and reactive oxygen species in reperfusion-induced arrhythmias and cardioprotection in chronically hypoxic rat hearts. Physiol Res 52: 52P, 2003.

KONERU S, VARMA PENUMATHSA S, THIRUNAVUKKARASU M, VIDAVALUR R, ZHAN L, SINGAL PK, ENGELMAN RM, DAS DK, MAULIK N: Sildenafil-mediated neovascularization and protection against myocardial ischaemia reperfusion injury in rats: role of VEGF/angiopoietin-1. J Cell Mol Med 12: 2651-2664, 2008.

MANUKHINA EB, MALYSHEV IY, SMIRIN BV, MASHINA SY, SALTYKOVA VA, VANIN AF: Production and storage of nitric oxide in adaptation to hypoxia. Nitric Oxide 5: 393-401, 1999.

MANUKHINA E, DOWNEY F, MALLET R: Role of nitric oxide in cardiovascular adaptation to intermittent hypoxia. Exp Biol Med (Maywood) 231: 343-365, 2006.

NECKÁŘ J, PAPOUŠEK F, NOVÁKOVÁ O, OŠŤÁDAL B, KOLÁŘ F: Cardioprotective effects of chronic hypoxia and ischaemic preconditioning are not additive. Basic Res Cardiol 97: 161-167, 2002.

NECKÁŘ J, OŠŤÁDAL B, KOLÁ̌̌ F: Myocardial infarct size-limiting effect of chronic hypoxia persists for five weeks of normoxic recovery. Physiol Res 53: 621-628, 2004.

NITZ RE, FIEDLER VB: Molsidomine: alternative approaches to treat myocardial ischemia. Pharmacotherapy 7: 2837, 1987.

OCKAILI R, SALLOUM F, HAWKINS J, KUKREJA RC: Sildenafil (Viagra) induces powerful cardioprotective effect via opening of mitochondrial K(ATP) channels in rabbits. Am J Physiol Heart Circ Physiol 283: H1263H1269, 2002.

OŠŤÁDAL B, KOLÁŘ F: Cardiac adaptation to chronic high-altitude hypoxia: Beneficial and adverse effects. Respir Physiol Neurobiol 158: 224-236, 2007. 
OŠŤÁDALOVÁ I, OŠŤÁDAL B, JARKOVSKÁ D, KOLÁŘ F: Ischemic preconditioning in chronically hypoxic neonatal rat heart. Pediatr Res 52: 561-567, 2002.

PEART JN, HEADRICK JP: Clinical cardioprotection and the value of conditioning responses. Am J Physiol Heart Circ Physiol 296: H1705-H1720, 2009.

ROUET-BENZINEB P, EDDAHIBI S, RAFFESTIN B, LAPLACE M, DEPOND S, ADNOT S, CROZATIER B: Induction of cardiac nitric oxide synthase 2 in rats exposed to chronic hypoxia. J Mol Cell Cardiol 31: 1697$1708,1999$.

SHI Y, PRITCHARD KA Jr, HOLMAN P, RAFIEE P, GRIFFITH OW, KALYANARAMAN B, BAKER JE: Chronic myocardial hypoxia increases nitric oxide synthase and decreases caveolin-3. Free Radic Biol Med 29: 695$703,2000$.

SHI Y, BAKER JE, ZHANG C, TWEDDELL JS, SU J, PRITCHARD KA: Chronic hypoxia increases endothelial nitric oxide synthase generation of nitric oxide by increasing heat shock protein 90 association and serine phosphorylation. Circ Res 91: 300-306, 2002.

ZHONG N, ZHANG Y, ZHU HF, WANG JC, FANG QZ, ZHOU ZN: Myocardial capillary angiogenesis and coronary flow in ischemia tolerance rat by adaptation to intermittent high altitude hypoxia. Acta Pharmacol Sin 23: 305$310,2002$. 